\title{
IDENTIFIKASI KESALAHAN JAWABAN MAHASISWA DITINJAU DARI KEMAMPUAN KOMUNIKASI MATEMATIS
}

\author{
Fitranto Eko Subekti $^{1)}$, Reni Untarti ${ }^{2)}$, Gunawan ${ }^{3)}$ \\ Pendidikan Matematika FKIP Universitas Muhammadiyah Purwokerto \\ efitrians@ymail.com ${ }^{1)}$; reniuntarti@gmail.com ${ }^{2}$; gun.oge@gmail.com ${ }^{3)}$
}

\begin{abstract}
Abstrak
Penelitian ini bertujuan untuk mengidentifikasi kesalahan jawaban mahasiswa dalam menyelesaikan soal pada mata kuliah statistika deskriptif ditinjau dari kemampuan komunikasi matematis. Jenis penelitian ini adalah penelitian deskriptif. Subyek penelitian adalah mahasiswa kelas IB sebanyak 36 mahasiswa. Teknik pengumpulan data dalam penelitian ini menggunakan tes. Berdasarkan hasil penelitian dapat disimpulkan bahwa kesalahan jawaban mahasiswa dalam menyelesaikan soal pada mata kuliah statistika deskriptif ditinjau dari kemampuan komunikasi matematis adalah sebagai berikut: (1) kesalahan menyajikan diagram sesuai dengan tujuan sebesar 30,56 \%; (2) kesalahan dalam menyajikan data ke dalam tabel distribusi frekuensi sebesar $27,78 \%$, (3) kesalahan menyajikan data dari histogram frekuensi ke dalam tabel distribusi frekuensi sebesar 22,22\%, dan (4) ketidakkonsistenan dalam penulisan simbol sebesar 36,11 \%. Berdasarkan hasil tersebut dapat dikatakan bahwa kesalahan yang paling banyak dilakukan mahasiswa ditinjau dari kemampuan komunikasi matematisnya adalah ketidakkonsistenan dalam menggunakan simbol.
\end{abstract}

Kata Kunci: Identifikasi kesalahan, Kemampuan komunikasi matematis

\section{Abstract}

This research aims to identify the error of students' answers to the quations of descriptive statistics viewed from mathematical communication skill. This is a descriptive research. The subjects of this research are 36 students of class IB. The technique of data collection used in this research is test. Based on the result of the research, it can be concluded that the errors of students' answers to the quations of descriptive statistics viewed from mathematical communication skill are: (1) the error in presenting diagram appropriate to the objective of $30.56 \%$; (2) the error in presenting data in the frequency distribution table of 27.78\%; (3) the error in presenting data from frequency histogram to frequency distribution table of $22.22 \%$; and (4) the inconsistency in writing symbol of 36.11\%. Based on the result, it is known that the most errors of the students' answer viewed from mathematical communication skill are the inconsistency in using the symbols. 
Keywords: Error identification, Mathematical Communication Skill

\section{A. PENDAHULUAN}

Mata kuliah statistika deskriptif merupakan salah satu mata kuliah wajib di Program Studi Pendidikan Matematika FKIP Universitas Muhammadiyah

Purwokerto. Mata kuliah ini bertujuan membekali mahasiswa agar mampu mengelompokkan dan menyajikan data dalam berbagai bentuk, baik tabel, diagram, maupun ukuran pemusatan, letak, dan penyebaran data, kemudian menafsirkannya. Mata kuliah ini penting diberikan kepada mahasiswa, karena mata kuliah ini menjadi dasar untuk mata kuliah selanjutnya, seperti: satatistika inferensia dan metodologi penelitian pendidikan. Selain itu mata kuliah ini juga membekali mahasiswa agar mampu mengajarkan materi statistika dalam jenjang sekolah menengah.

Seperti diketahui bahwa statistika dibagi menjadi 2, statistika deskriptif dan statistika inferensia. Dalam statistika deskriptif mahasiswa belajar bagaimana mengelompokkan dan menyajikan data, sedangkan pada statistika inferensia mahasiswa belajar bagaimana menganalisis dan menginterpretasikan data, serta mengeneralisasikan kesimpulan. Adapun materi yang diajarkan dalam mata kuliah statistika deskriptif Program Studi Pendidikan Matematika FKIP Universitas Muhammadiyah Purwokerto meliputi: (1) konsep dasar statistika; (2) penyajian data; (3) distribusi frekuensi; (4) ukuran pemusatan data; (5) ukuran letak; (6) ukuran penyebaran data; dan (7) skewness dan kurtosis.

Untuk mengetahui apakah mahasiswa sudah menguasai materi dari mata kuliah yang dipelajari, maka perlu dilakukan tes atau penilaian terhadap mahasiswa tersebut. Menurut Sudijono (1995); Supranata (2005); Arikunto (2010) dan Sukardi (2010) tes merupakan sekumpulan pertanyaan, pernyataan, atau tugas yang harus dikerjakan, ditanggapi, atau dilakukan sesuai dengan aturan yang ditentukan sebagai alat pengukur keberhasilan peserta didik dan program pengajaran yang dilakukan. Tes yang diberikan sebaiknya mengukur kemampuan atau performa sesuai tujuan yang diinginkan. Ada berbagai macam kemampuan matematis yang harus dimiliki oleh peserta didik dalam memahami materi statistika deskriptif. Salah satu kemampuan tersebut adalah kemampuan komunikasi matematis.

Komunikasi merupakan bagian penting dari matematika dan pendidikan matematika, karena melalui komunikasi, ide dapat tersampaikan dan proses pemahaman terjadi. Ketika peserta didik tertantang untuk berpikir dan menyampaikan ideidenya baik secara lisan maupun tulisan, maka proses komunikasi sedang terjadi. Hardjana (2003); Effendy (2007) dan Mulyana (2008) menyatakan bahwa komunikasi merupakan pemberitahuan, 
pembicaraan, percakapan, pertukaran pikiran, oleh komunikator kepada komunikan melalui media yang menimbulkan efek tertentu baik secara verbal maupun non verbal.

NCTM (2000) menyatakan bahwa komunikasi matematis merupakan kemampuan seseorang untuk menggorganisasi, mengkomunikasikan gagasan matematika menggunakan bahasa matematika secara logis dan jelas kepada orang lain serta menganalisis dan mengevaluasi pikiran matematika dan strategi yang digunakan orang lain. Ada 3 indikasi peserta didik telah memiliki kemampuan komunikasi matematis menurut NCTM (2000), yaitu: (1) mampu menyampaikan ide matematis baik secara lisan, verbal, maupun visual; (2) mampu menginterpretasikan ide matematis yang disajikan dalam bentuk tulisan maupun visual; serta (3) mampu menggunakan simbol dan struktur matematika secara tepat. Sejalan dengan pernyataan tersebut John (2008) menyatakan bahwa indikasi peserta didik telah memiliki kemampuan komunikasi matematis, jika peserta didik tersebut telah mampu mengkoordinasi ide matematika dan menyampaikan ide tersebut dengan menggunakan bahasa matematika secara koheren dan jelas, serta mampu menganalisis dan menilai ide matematis yang disampaikan oleh orang lain.

Setelah mahasiswa dites,
jawaban mahasiswa

diidentifikasi kesalahannya. Hal ini bertujuan agar diketahui letak dan jenis kesalahan yang telah dilakukan oleh mahasiswa dalam materi tertentu. Karena salah satu kemampuan yang harus dimiliki mahasiswa dalam mempelajari statistika deskriptif adalah kemampuan komunikasi matematis, maka identifikasi kesalahan mahasiswa dapat ditinjau dari kemampuan komunikasi matematisnya. Beberapa kesalahan yang dapat dilihat dari kemampuan komunikasi matematis sesuai dengan tujuan mata kuliah statistika deskriptif, yaitu: (1) kesalahan dalam menyajikan data dalam bentuk diagram sesuai dengan tujuannya; (2) kesalahan dalam menyajikan data tunggal ke dalam tabel distribusi frekuensi; (3) kesalahan dalam menyajikan data dari histogram frekuensi atau ogif ke dalam tabel distribusi frekuensi; serta (4) ketidakkonsistenan dalam menggunakan simbol matematika.

\section{Berdasarkan permasalahan tersebut, peneliti tertarik ingin mengidentifikasi kesalahan jawaban mahasiswa ditinjau dari kemampuan komunikasi matematis mahasiswa Program Studi Pendidikan Matematika yang mengambil mata kuliah statistika deskriptif.}

\section{B. METODE PENELITIAN}

Jenis penelitian yang dilakukan peneliti adalah penelitian kualitatif. Adapun metode yang digunakan adalah metode penelitian deskriptif dengan pendekatan kuantatif dan kualitatif. Deskriptif kuantitatif 
menggambarkan besar persentase kesalahan jawaban mahasiswa ditinjau dari kemampuan komunikasi matematis, sedangkan deskriptif kualitatif menggambarkan kesalahan jawaban mahasiswa dalam menyelesaikan soal ditinjau dari kemampuan komunikasi matematis. Subjek penelitian adalah mahasiswa Program Studi Pendidikan Matematika yang mengambil mata kuliah Statistika Deskriptif.

Prosedur penelitian yang dilakukan oleh peneliti adalah sebagai berikut: (1) memberikan tes; dan 2) mengidentifikasi kesalahan jawaban mahasiswa dalam menjawab soal ditinjau dari kemampuan komunikasi matematisnya. Tes diberikan kepada mahasiswa kelas IB yang mengambil mata kuliah statistika deskriptif sejumlah 36 mahasiswa. Berdasarkan hasil tes tersebut kemudian diidentifikasi kesalahannya ditinjau dari kemampuan komunikasi matematis mahasiswa. Hasil tersebut kemudian dibuat persentase untuk setiap aspek kesalahannya. Selain itu, pada pembahasan juga diberikan beberapa contoh kesalahan-kesalahan jawaban mahasiswa ditinjau dari kemampuan komunikasi matematisnya.

\section{HASIL DAN PEMBAHASAN}

Tahap pertama yang dilakukan yaitu memberikan tes kepada mahasiswa kelas IB yang mengambil mata kuliah statistika deskriptif. Tes tersebut terdiri dari 4 soal uraian dan diikuti oleh 36 mahasiswa. Berdasarkan hasil tes tersebut diidentifikasi kesalahan jawaban mahasiswa ditinjau dari kemampuan komunikasi matematisnya. Adapun hasil penelitian yang dimaksud sebagai berikut.

Tabel 1. Kesalahan jawaban mahasiswa ditinjau dari kemampuan

komunikasi matematis

\begin{tabular}{|l|l|l|}
\hline No & \multicolumn{1}{|c|}{ Jenis Kesalahan } & $\begin{array}{l}\text { Mahasiswa yang melakukan } \\
\text { kesalahan }\end{array}$ \\
\hline 1. & $\begin{array}{l}\text { Kesalahan menyajikan data ke dalam bentuk } \\
\text { diagram sesuai dengan tujuannya }\end{array}$ & $\begin{array}{l}\text { B36, B37, B41, B43, B46, } \\
\text { B47, B54, B55, B56, B67, B68 }\end{array}$ \\
\hline 2. & $\begin{array}{l}\text { Kesalahan menyajikan data tunggal ke } \\
\text { dalam tabel distribusi frekuensi }\end{array}$ & $\begin{array}{l}\text { B36, B40, B41, B49, B52, } \\
\text { B62, B63, B65, B66, B69 }\end{array}$ \\
\hline 3. & $\begin{array}{l}\text { Kesalahan menyajikan data dari histogram } \\
\text { frekuensi atau ogif ke dalam tabel distribusi } \\
\text { frekuensi }\end{array}$ & $\begin{array}{l}\text { B36, B41, B42, B43, B49, } \\
\text { B50, B58, B64 }\end{array}$ \\
\hline 4. & $\begin{array}{l}\text { Ketidakkonsistenan dalam menggunakan } \\
\text { simbol matematika }\end{array}$ & $\begin{array}{l}\text { B38, B39, B42, B45, B46, } \\
\text { 347, B51, B54, B56, B61, } \\
\text { B63, B66, B69 }\end{array}$ \\
\hline
\end{tabular}

Berdasarkan tabel 1 di atas terlihat bahwa 11 mahasiswa melakukkan kesalahan dalam menyajikan data ke dalam bentuk 
diagram sesuai dengan tujuannya. Namun dari 25 mahasiswa yang menjawab benar, 15 mahasiswa menyajikan data dalam bentuk kurang lengkap, yaitu kurang adanya keterangan atau judul dari diagram yang disajikan. Kurangnya keterangan dan judul dalam diagram berakibat penyampaian informasi dari diagram tersebut menjadi tidak lengkap dan kurang optimal. Lima belas mahasiswa tersebut adalah: B45, B48, B50, B51, B53, B59, B62, B63, B64, B65, B66, B69, B70 B71 dan B72.
Hasil ini didukung oleh hasil jawaban mahasiswa pada soal tentang tujuan penggambaran masing-masing diagram. Berdasarkan hasil jawaban tersebut, dihasilkan hanya 14 mahasiswa yang mampu menyebutkan tujuan penggambaran masing-masing diagram secara benar dan lengkap, sedangkan sisanya hanya sebagian benar dan terbolak-balik. Berikut soal dan contoh kesalahan yang dilakukan mahasiswa terkait penyajikan data dalam bentuk diagram sesuai dengan tujuannya.

\section{Soal tentang penyajian data dalam bentuk diagram sesuai dengan tujuannya}

Berikut adalah tren produksi motor dari tahun 2005 sampai dengan 2014

Tabel 1. Data produksi motor dalam ribuan

\begin{tabular}{|l|l|l|l|l|l|l|l|l|l|l|}
\hline Tahun & 2005 & 2006 & 2007 & 2008 & 2009 & 2010 & 2011 & 2012 & 2013 & 2014 \\
\hline Omset & 100 & 101 & 100,5 & 102 & 102,5 & 103 & 104 & 106 & 105,5 & 107 \\
\hline
\end{tabular}

Berdasarkan data dalam tabel 1) di atas, gambarkanlah kedalam diagram yang paling sesuai.

\section{Jawaban mahasiswa B41 dan B72 tentang kesalahan menyajikan data dalam} bentuk diagram sesuai dengan tujuan.
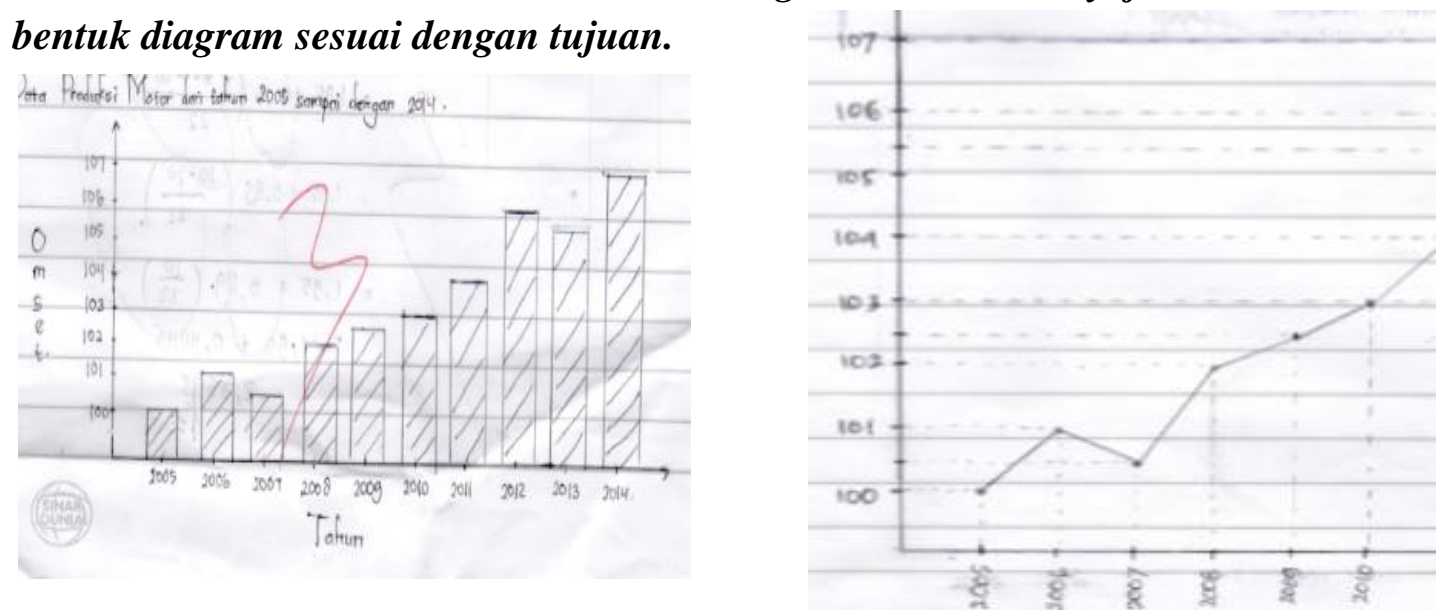

Gambar 1. Jawaban mahasiswa B41 dan B72 terkait penyajian data dalam bentuk diagram sesuai dengan tujuannya

Berdasarkan gambar 1. di atas terlihat bahwa mahasiswa B41 belum dapat memahami penggunaan diagram sesuai dengan tujuannya. Mahasiswa
B41 menggambarkan persoalan tersebut dengan diagram batang. Hal ini kurang tepat karena persoalan yang disajikan terkait dengan tren kenaikan 
atau penurunan produksi motor dari tahun 2005 s.d. tahun 2014 bukan perbandingan produksi tiap tahun. Mahasiswa $\quad$ B72 sudah menggambarkan diagram sesuai dengan tujuan yang diinginkan, hanya saja mahasiswa B72 dalam menggambarkan diagram garisnya kurang lengkap. Hal ini terlihat pada gambar tersebut tanpa adanya keterangan maupun judul dari diagram tersebut. Ketidaklengkapan keterangan yang diberikan pada diagram tersebut, menjadikan informasi yang disajikan oleh diagram kurang lengkap dan akan menimbulkan banyak penafsiran. Dengan kata lain, mahasiswa B41 telah melakukan kesalahan dalam menyajikan diagram sesuai dengan tujuan yang sesuai, sedangkan mahasiswa B72 melakukan kesalahan, yaitu kurang lengkapnya keterangan dalam menyajikan data ke dalam diagram sesuai dengan tujuan yang diinginkan.

Hasil identifikasi kesalahan jawaban mahasiswa dalam menyajikan data tunggal ke dalam tabel distribusi frekuensi diperoleh 10 mahasiswa yang melakukan kesalahan tersebut seperti tabel 1 di atas. Adapun rincian kesalahannya adalah sebagai berikut: 4 mahasiswa, yaitu: B36, B52, B62 dan B63 menyajikan ke dalam tabel frekuensi biasa, 3 mahasiswa, yaitu: B40, B41, dan B69 salah dalam menentukan ujung kelas, dan 3 mahasiswa, yaitu: B49, B65, dan B66 kurang teliti, sehingga penulisan frekuensi pada tabel tersebut menjadi salah. Berikut soal dan contoh jawaban mahasiswa soal tentang menyajikan data tunggal ke dalam tabel distribusi komulatif.

\section{Soal tentang menyajikan data dalam bentuk tabel distribusi frekuensi}

Perhatikan data pengukuran panjang dari 30 besi ulir berikut : 4,6; 4,4; 2,3; 3,$2 ; 2,8 ; 3,3 ; 4,5 ; 2,9 ; 3,2 ; 3,4 ; 4,5 ; 2,9 ; 2,1 ; 4,4 ; 4,8 ; 2,4 ; 2,7 ; 3,1 ; 4,1 ; 3,2$; 2,$9 ; 3,4 ; 2,7 ; 4,1 ; 3,6 ; 3,3 ; 3,7 ; 3,7 ; 4,8 ; 4,8$.

Berdasarkan data tersebut buatlah daftar distribusi frekuensinya.

Jawaban mahasiswa B40 dan B52 untuk kesalahan menyajikan data ke dalam tabel distribusi frekuensi.
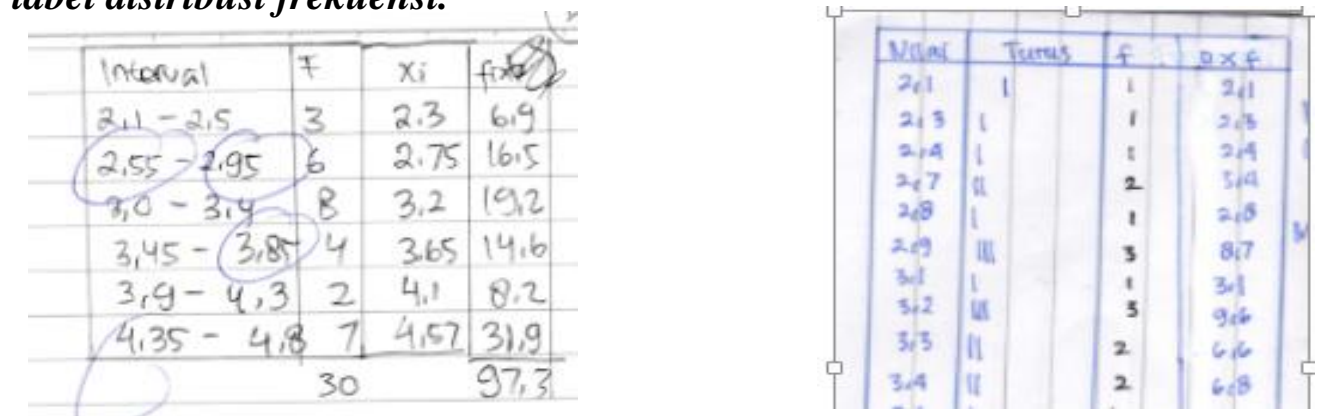

Gambar 2. Jawaban mahasiswa B40, dan B52 
Pada gambar 2 di atas terlihat bahwa mahasiswa B40 melakukan kesalahan dalam menyajikan data ke dalam tabel distribusi frekuensi. Mahasiswa B40 tidak konsisten dalam menuliskan ujung bawah kelas dan ujung atas kelas, ada yang menggunakan satu angka desimal, tetapi juga ada yang menggunakan 2 angka desimal. Selisih yang digunakan antar ujung atas pertama dengan ujung bawah kelas kedua adalah 0,05 bukan 0,1. Mahasiswa B52, melakukan kesalahan dalam menyajikan data ke dalam tabel distribusi frekuensi. mahasiswa B52 menyajikan data ke dalam tabel frekuensi biasa dan tidak menyajikannya ke dalam tabel distribusi frekuensi yang diinginkan soal. Selain itu, pemberian nama atribut pada tabel frekuensi tersebut, juga tidak sesuai yang diinginkan soal.
Mahasiswa B52 memberikan atribut pada kolom pertama dengan "nilai", padahal dalam informasi yang diberikan adalah tentang panjang besi ulir, sehingga informasi yang diberikan tabel tersebut menjadi salah.

Hasil identifikasi kesalahan jawaban mahasiswa dalam mengubah histogram frekuensi ke dalam tabel distribusi frekuensi diperoleh 8 mahasiswa yang melakukan kesalahan tersebut. Adapun rinciannya adalah sebagai berikut: 7 mahasiswa, yaitu: B41, B42, B43, B49, B50, B58, B64 salah dalam menentukan ujung bawah dan atas kelas, sedangkan B36 tidak menjawab pertanyaan tersebut. Berikut soal dan jawaban mahasiswa terkait soal tentang menyajikan data dari histogram frekuensi ke dalam tabel distribusi frekuensi.

\section{Soal tentang menyajikan data dari histogram frekuensi ke dalam tabel distribusi frekuensi}

Perhatikan histogram dan polygon frekuensi berikut :

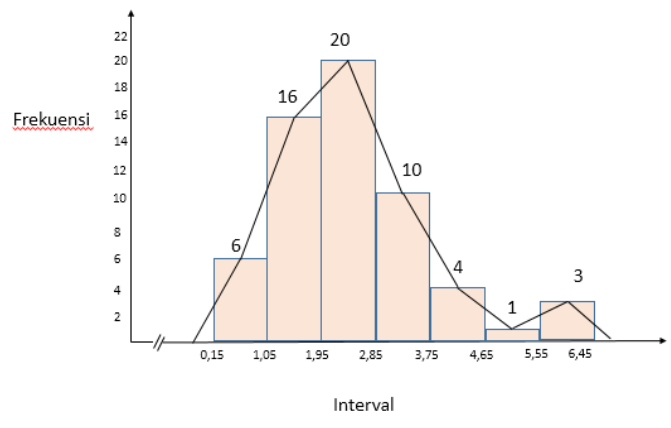

Berdasarkan histogram dan polygon frekuensi tersebut, sajikanlah ke dalam tabel distribusi frekuensi. 
Jawaban mahasiswa B42 dan B50 terkait soal tentang penyajian data dari
histogram frekuensi ke dalam tabel distribusi frekuensi.

\begin{tabular}{|c|c|c|}
\hline Nilai Intorval & $f i$ & $f i$ \\
\hline $0,155-1,045$ & 6 & 6 \\
\hline $1,046-1,945$ & 16 & 22 \\
\hline $1,946-2,845$ & 20 & 42 \\
\hline $2,846-3,745$ & 10 & 52 \\
\hline $3,746-4,645$ & 4 & 56 \\
\hline $4,646-5,545$ & 1 & 57 \\
\hline $5,546-6,445$ & 3 & 60 \\
\hline & 60 & \\
\hline
\end{tabular}

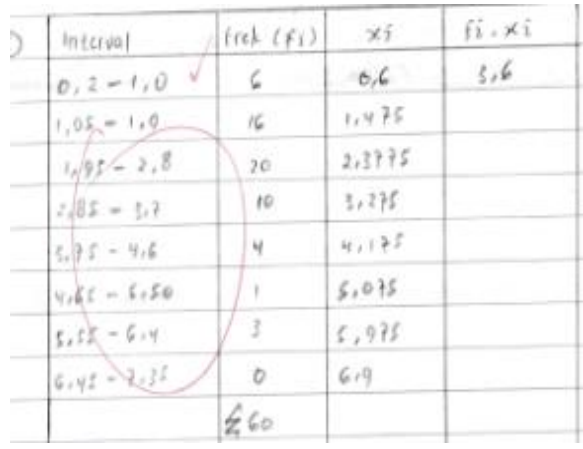

Gambar 3. Jawaban mahasiswa B42 dan B50

Jawaban mahasiswa B42 pada gambar 3 di atas menunjukkan bahwa mahasiswa melakukan kesalahan dalam menyajikan data dari histogram frekuensi ke dalam tabel distribusi frekuensi. Mahasiswa B42 menambahkan 0,005 dengan batas kelas pertama untuk ujung bawah kelas pertama, batas bawah kelas kedua dikurangi 0,004 untuk ujung kelas kedua, dan ujung bawah kelas ketiga, keempat dan seterusnya mahasiswa mendapatkan ujung bawah kelas dengan cara batas bawah kelas dikurangi 0.004. Dari jawaban tersebut mahasiswa diduga mencari ujung bawah kelas dengan cara mengurangi batas kelas dengan 0.004, dan mencari ujung kelas atas dengan cara batas atas kelas dikurangi dengan 0,005. Berdasarkan jawaban tersebut diduga mahasiswa B42 salah dalam memahami pengertian antara batas kelas dengan ujung kelas.

Jawaban mahasiswa B50 dari gambar 3 di atas terlihat bahwa mahasiswa B50 melakukan kesalahan dalam menyajikan data dari histogram frekuensi ke dalam tabel distribusi

frekuensi. Mahasiswa B50 terlihat kebingungan dalam menentukan ujung bawah kelas dan ujung atas kelas, hal ini terlihat dari jawaban yang diberikan mahasiswa B50 sudah benar dalam menentukan kelas yang pertama, tetapi salah dalam menentukan kelas kedua, ketiga, dan seterusnya. Selain itu, mahasiswa dalam menentukan ujung bawah kelas kedua dengan cara menambahkan 0,5 dengan ujung atas kelas pertama, begitu juga dengan ujung bawah kelas ketiga ditentukan dengan cara menambahkan 0,5 dengan ujung atas kelas kedua. Hal ini menyebabkan panjang kelas yang sudah dicari adalah 0,9, untuk kelas kedua dan kelas ketiga, dan seterusnya panjang kelasnya hanya 0,85 . Akibatnya, pada tabel distribusi frekuensi yang dibuat responden B50 panjang kelasnya tidak sama. Diduga mahasiswa kurang teliti dalam menyajikan data dari histogram frekuensi ke dalam tabel distribusi frekuensi. 
Kesalahan yang muncul terkait dengan kemampuan komunikasi matematis adalah kekonsistenan dalam penggunaan simbol, sebagian besar mahasiswa sudah mampu menggunakan simbol secara konsisten, hanya 13 mahasiswa yang dalam penulisan simbolnya belum konsisten. Adapun rinciannya adalah sebagai berikut: 3 mahasiswa, yaitu: B45, B63, dan B66 menggunakan simbol " $\mathrm{f}$ " dan "fi" untuk menyatakan frekuensi, mahasiswa B51 menggunakan simbol " $\Sigma$ fi" dan " $\Sigma$ n" untuk menyatakan jumlah frekuensi, mahasiswa B46 dan B69 menggunakan simbol "Fi" dan

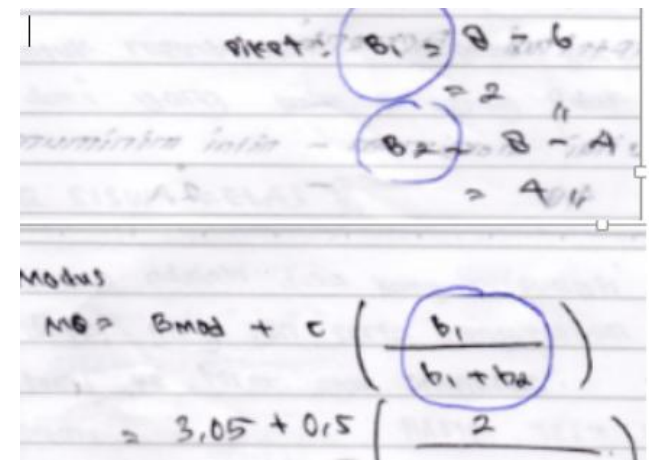

"fi" untuk menyatakan frekuensi, mahasiswa B54 menggunakan simbol "b1, b2" dengan "B1, B2" pada saat mencari nilai modus, mahasiswa $\mathrm{B} 47$, B56 menggunakan simbol "Fi" dengan "f" untuk menyatakan frekuensi dan 4 mahasiswa, yaitu: B38, B39, B42 dan B61 menggunakan "frekuensi" dengan "f" untuk menyatakan frekuensi. Berdasarkan kesalahan-kesalahan tersebut, terlihat bahwa ketidakkonsistenan mahasiswa, mayoritas pada saat menyatakan frekuensi. Berikut beberapa jawaban mahasiswa terkait ketidakkonsistenan dalam penggunaan simbol.

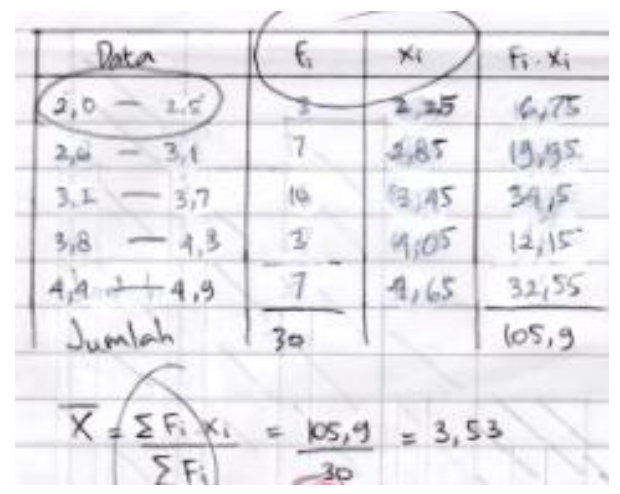

Gambar 4. Jawaban mahasiswa B54 dan B46

Pada gambar 4 di atas terlihat bahwa mahasiswa B54 tidak konsisten dalam menggunakan simbol untuk frekuensi sebelum dan sesudah kelas modus. Mahasiswa B54 menggunakan simbol " $\mathrm{B}_{1}$ " dan " $\mathrm{b}_{1}$ " untuk menyatakan selisih antara frekuensi kelas modus dengan frekuensi sebelum kelas modus dan menggunakan simbol " $\mathrm{B}_{2}$ " dan " $\mathrm{b}_{2}$ " untuk menyatakan simbol selisih antara frekuensi kelas modus dengan frekuensi sesudah kelas modus. Mahasiswa B46 tidak konsisten dalam menuliskan simbol frekuensi. Pada tabel distribusi mahasiswa B46 menggunakan simbol " $f_{i}$ " dan " $F_{i}$ ", sedangkan pada rumus mean mahasiswa B46 menggunakan simbol "F.". Dua gambar gambar di atas menunjukkan bahwa mahasiswa melakukan kesalahan, yaitu ketidakkonsistenan dalam penggunaan simbol matematika. Simbol yang berbeda akan menunjukkan arti yang berbeda. Selain ketidakkonsistenan dalam penggunaan simbol, mahasiswa B46 dalam penamaan atribut kolom 
pertama kurang spesifik. Mahasiswa hanya memberikan nama data, pemberian nama data kurang jelas dan berakibat informasi yang diberikan menjadi kurang lengkap.

Selain kesalahan-kesalahan tersebut di atas, berdasarkan jawaban responden juga ditemukan kesalahankesalahan yang lain, yaitu: kesalahan dalam menghitung, dan kesalahan dalam menggunakan rumus. Kesalahan menghitung dilakukan oleh 23 mahasiswa, yaitu: mahasiswa B37, B38, B39, B40, B41, B42, B43, B45, B46, B47, B49, B50, B54, B55, B57, B58, B62, B63, B64, B65, B66, B69, dan mahasiswa B72 sedangkan kesalahan dalam menggunakan rumus dilakukan oleh 2 mahasiswa, yaitu: B62, dan B66.

\section{Jawaban responden terkait kesalahan dalam menggunakan rumus}
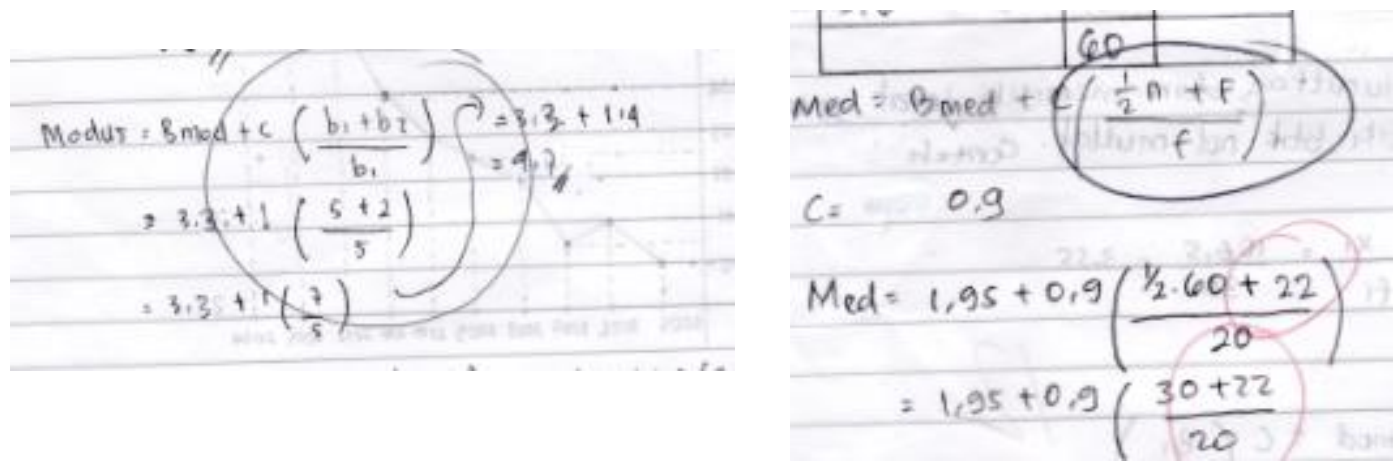

Gambar 5. Jawaban mahasiswa B62 dan B65 terkait kesalahan dalam menggunakan rumus

Jawaban mahasiswa B62 pada gambar 5 di atas menujukkan bahwa mahasiswa telah salah menuliskan rumus untuk mencari nilai modus. Mahasiswa B62 menuliskan $\frac{b_{1}+b_{2}}{b_{1}}$, yang seharusnya adalah $\frac{b_{1}}{b_{1}+b_{2}}$. Mahasiswa B62 juga salah dalam menentukan panjang kelas. Selain itu, B62 menuliskan panjang kelas satu, padahal panjang kelas yang diinginkan adalah 0,5. Kesalahan lainnya yang dilakukan oleh B62 adalah pemahaman tentang simbol " $b_{1}$ " dan " $b_{2}$ " yang terbalik. Mahasiswa menyatakan simbol " $b_{1}$ " untuk selisih antara frekuensi kelas modus dengan frekuensi kelas sesudahnya, dan menyatakan simbol " $b_{2}$ " untuk selisih antara frekuensi kelas modus dengan frekuensi sebelumnya. Mahasiswa juga salah dalam menentukan batas bawah kelas modusnya. Mahasiswa B65 salah menulis rumus untuk mencari nilai median. Mahasiswa B65 menuliskan rumus $\frac{\frac{1}{2} n+F}{f}$, yang seharusnya $\frac{\frac{1}{2} n-F}{f} . \quad$ Kesalahan penulisan rumus berakibat kesalahan 
dalam menyelesaikan soal modus dan median tersebut. disajikan dalam bentuk persentase, didapatkan tabel sebagai berikut:

Apabila hasil identifikasi kesalahan jawaban mahasiswa tersebut

Tabel 2. Persentase jenis kesalahan ditinjau dari kemampuan komunikasi matematis

\begin{tabular}{|l|l|c|}
\hline \multicolumn{1}{|c|}{ No } & \multicolumn{1}{|c|}{ Jenis Kesalahan } & Persentase (\%) \\
\hline 1. & $\begin{array}{l}\text { Kesalahan menyajikan data ke dalam bentuk diagram } \\
\text { sesuai dengan tujuannya }\end{array}$ & 30,56 \\
\hline 2. & $\begin{array}{l}\text { Kesalahan menyajikan data tunggal ke dalam tabel } \\
\text { distribusi frekuensi }\end{array}$ & 27,78 \\
\hline 3. & $\begin{array}{l}\text { Kesalahan menyajikan data dari histogram frekuensi atau } \\
\text { ogif ke dalam tabel distribusi frekuensi }\end{array}$ & 22,22 \\
\hline 4. & $\begin{array}{l}\text { Ketidakkonsistenan dalam menggunakan simbol } \\
\text { matematika }\end{array}$ & 36,11 \\
\hline
\end{tabular}

Selain kesalahan tersebut, 63,89 \% mahasiswa salah dalam menghitung, dan 5,56\% mahasiswa salah dalam menggunakan rumus. Berdasarkan hasil tersebut dapat dikatakan jenis kesalahan jawaban mahasiswa ditinjau dari kemampuan komunikasi matematis yang dilakukan oleh mahasiswa paling banyak adalah penggunaan simbol yang tidak konsisten.

Selain itu, berdasarkan temuan yang didapat peneliti, kebanyakan mahasiswa sudah mampu memahami konsep dari mata kuliah statistika deskriptif, hanya saja masih kurang teliti dalam melakukan perhitungan. Ada temuan menarik yang diperoleh peneliti, yaitu: sebagian besar mahasiswa dalam menuliskan simbol tanpa disertai dengan permisalahan terlebih dahulu. Sehingga informasi yang ingin diberikan tidak tersampaikan dengan sempurna.
Dengan kata lain, mayoritas mahasiswa sudah mampu menuliskan rumus yang akan digunakan, tetapi tanpa disertai dengan penjelasan untuk setiap simbol yang diberikan. Diduga mahasiswa menganggap yang penting adalah benar rumus dan perhitungannya, tanpa memikirkan arti pentingnya penjelasan dari masingmasing simbol tersebut.

\section{KESIMPULAN}

Berdasarkan hasil dan pembahasan di atas dapat disimpulkan bahwa kesalahan jawaban mahasiswa dalam menyelesaikan soal statistika deskriptif ditinjau dari kemampuan komunikasi matematis adalah sebagai berikut: (1) kesalahan menyajikan diagram sesuai dengan tujuan sebesar $30,56 \%$; (2) kesalahan dalam menyajikan data ke dalam tabel distribusi frekuensi sebesar $27,78 \%$, (3) kesalahan menyajikan data dari histogram frekuensi ke dalam tabel 
distribusi frekuensi sebesar 22,22\%, dan (4) ketidakkonsistenan dalam penulisan simbol sebesar $36,11 \%$.

\section{DAFTAR PUSTAKA}

Arikunto, S. (2010). Dasar-Dasar Evaluasi Pendidikan (Edisi Revisi). Jakarta: Bumi Aksara.

Effendy, O. U. (2007). Ilmu Komunikasi. Bandung: PT Remaja Rosdakarya.

Hardjana, A. M. (2003). Komunikasi interpersonal dan intrapersonal. Yogyakarta: Kanisius.

John. A. (2008). Matematika Sekolah Dasar dan Menengah. Jakarta: Erlangga.

Mulyana, D. (2008). Komunikasi Efektif. Bandung: PT Remaja Rosdakarya.

NCTM. (2000). Principles and standarts for school mathematics. Reston VA: The National Council of Teachers of Mathematics, Inc.

Sudijono, A. (1995). Pengantar Evaluasi Pendidikan. Jakarta: PT Rajagrafindo Persada.

Sukardi. 2010. Evaluasi Pendidikan Prinsip \& Operasionalnya. Jakarta: Bumi Aksara.

Surapranata, S. (2005). Panduan Penulisan Tes Tertulis Implementasi Kurikulum 2004. Bandung: PT Remaja Rosdakarya. 